\title{
ARAŞTIRMA / RESEARCH \\ Predictive values of lamina cribrosa depth and ganglion cell complex thickness in early diagnosis of glaucoma
}

Glokom erken tanısında lamina kribroza derinliği ve ganglion hücre kompleks kalınlığı ölçümlerinin değerlendirilmesi

\author{
Şule Barman Kakil'D, Elif Erdem² (D), İbrahim İnan Harbiyeli2 (D), Meltem Yağmur² (D) \\ ${ }^{1}$ Dışkapı Yıldırım Beyazıt Research and Training Hospital, Department of Ophthalmology, Ankara, Turkey \\ ${ }^{2}$ Cukurova University Faculty of Medicine, Department of Ophthalmology, Adana, Turkey
}

\section{Cukurova Medical Journal 2022;47(1):259-265.}

\begin{abstract}
Purpose: Evaluation of ganglion cell complex measurement and the use of parameters of lamina cribrosa depth in early diagnosis and progression of patients with suspected glaucoma.

Materials and Methods: Measurements were taken with Heidelberg Spectralis Spectral Domain Optical Coherence Tomography from patients in both groups. Ganglion cell complex thicknesses measured with segmentation analysis. Lamina cribrosa depths were measured by using optic nerve head images of the glaucoma suspected group and the control group.

Results: Thirty-one glaucoma suspect patients and 42 healthy individuals were included in the study. The thickness of the ganglion cell layer was $11.46 \mu$ in the glaucoma suspect group, and it was $12.19 \mu$ in the control group. Mean lamina cribrosa depth was $579.3 \mu$ in the glaucoma suspected group and $399.62 \mu$ in the control group.

Conclusion: Optical coherence tomography helps ophthalmologists for the diagnosis and follow-up of glaucoma patients, and non-invasively measured ganglion cell layer and lamina cribrosa depth may be a guide for early diagnosis. In this study, lamina cribrosa depth difference is more significant in the glaucoma suspect group so this parameter can be used in early diagnosis.

Keywords: Ganglion cell complex thickness; glaucoma suspect; lamina cribrosa depth; optical coherence tomography
\end{abstract}

Öz

Amaç: Glokom şüphesi ile takip edilen hastaların erken tanı ve progresyonunda ganglion hücre kompleksi ölçümünün ve lamina cribrosa derinliği parametrelerinin kullanımının değerlendirilmesidir.

Gereç ve Yöntem: Glokom şüpheli ve kontrol grubu katılımcilarından Heidelberg Spectralis Spectral Domain Optik Koherens Tomografi ile ölçümler alındı. Her iki grupta ganglion hücre kompleksi kalınlıkları segmentasyon analizi ile lamina kribroza derinlikleri de katılımciların optik sinir başı görüntüleri kullanılarak ölçüldü.

Bulgular: Çalışmaya 31 glokom şüpheli hasta ve 42 sağlıklı birey dahil edildi. Glokom şüpheli grupta ganglion hücre tabakası kalınlığ $11.46 \mu$, kontrol grubunda $12.19 \mu$ idi. Ortalama lamina kribroza derinliği glokom şüphesi olan grupta $579.3 \mu$, kontrol grubunda $399.62 \mu$ idi.

Sonuç: Optik koherens tomografi, glokom hastalarının tanı ve takibinde oftalmologlara yardımc1 olur ve noninvaziv olarak ölçülen ganglion hücre tabakası ve lamina kribroza derinliği erken tanı için yol gösterici olabilir. Bu çalışmada glokom şüphesi olan grupta lamina cribrosa derinlik farkı daha belirgin olduğundan bu parametre erken tanıda kullanılabilir.

Anahtar kelimeler: Ganlion hücre tabakası kalınlığ1; glokom şüphesi; lamina kribroza derinliği; optik koherens tomografi

\footnotetext{
Yazışma Adresi/Address for Correspondence: Dr. Şule Barman Kakil, Dışkapı Yıldırım Beyazıt Research and Training Hospital, Department of Ophthalmology, Ankara, Turkey E-mail: drsule_barman@hotmail.com
} Geliş tarihi/Received: 28.11.2021 Kabul tarihi/Accepted: 15.02.2022 


\section{INTRODUCTION}

Glaucoma is a chronic optic neuropathy marked by progressive optic nerve damage and characteristic visual field changes by retinal ganglion cell death ${ }^{1}$. As a result of studies carried out in the last 20 years, imaging technologies have been developed to detect the damage caused by glaucoma in the early stages. One of them is optical coherence tomography (OCT), in which non-invasively imaging tecnique using low coherence interferometry to produce highresolution images of the retina in $3-\mathrm{D}^{2}$. The tomographic images of the optic disc and retina are obtained by using the reflection of infrared light from tissue layers like the B-mode ultrasound principle. In this way, the OCT allows the retinal nerve fiber layer (RNFL) thickness to be measured and the optical nerve head parameters can be obtained by distinguishing the retinal layers. In glaucoma, the RNFL and ganglion cell with the inner plexiform layer (IPL) are clinically valuable markers of glaucoma and tend to thin as the disease progresses. As a result, this imaging procedure is now commonly used in the detection and treatment of glaucoma ${ }^{3,4}$.

Glaucoma suspect patients have an increased risk for glaucomatous optic nerve degeneration and visual loss. A glaucoma suspect has clinical symptoms that are suggestive but not conclusive of open angle glaucoma. The definition of glaucoma suspect is based on the European Glaucoma Society(EGS) guideline criteria. Visual field and/or optic disc and/or RNFL normal or suspicious, with at least one being suspicious. Intraocular pressure in glaucoma suspect patients may be normal or elevated ${ }^{5-7}$.

Posterior deformation of lamina cribrosa is a pathogenic issue in the mechanical theory of glaucoma ${ }^{8}$. This hypothesis is based on experimental studies. Studies showed that optic nerve deformation is becoming earlier than surface structural damage ${ }^{9,10}$.

The posterior deformation of lamina cribrosa is regarded to cause axonal and/or retinal ganglion cell destruction with various ways. These mechanisms include axonal transport blockade and tissue remodeling by reactive astrocytes ${ }^{11-14}$. Moreover, nutrition from the capillaries to adjacent axons can be affected by compression lamina cribrosa ${ }^{15}$.

Macular ganglion cell complex can be expressed by the total of the macular nerve fibers, ganglion cells, and IPL ${ }^{16}$. Ganglion cell complex (GCC) measurements acquired automatically with the latest
OCT devices, and recent studies show that a decrease in macular ganglion cell complex thickness like RNFL parameters have high importance in diagnosing early glaucoma ${ }^{17-20}$.

The hypothesis of our study is that both GCC and lamina cribrosa depth (LCD) measurements could be used in early early diagnosis of glaucoma. On the basis the aim of our study was to evaluate association between progression of disease and the ganglion cell layer and lamina cribrosa depth parameters as measured by OCT in patients with suspected glaucoma.

\section{MATERIALS AND METHODS}

\section{Study design and sample}

In this study, ganglion cell layer thicknesses and lamina cribrosa depths were assessed using optical coherence tomography from healthy individuals who had no ophthalmologic problem and patients have been followed up with glaucoma suspect in the Department of Ophthalmology at Çukurova University Faculty of Medicine.

This study approved the ethical committee of Çukurova University (Date:03/01/2017 Number:23) and informed consent was obtained. This study was performed in consistency with the guideline of the the Declaration of Helsinki. Medical files and ophthalmologic examination records of glaucoma patients who have been followed at Çukurova University Faculty of Medicine, in Department of Ophthalmology, were analyzed. Patient clinical data, history of any ophthalmologic disease were determined, and ophthalmologic examination was conducted at the time of clinical admission. Patients who were followed up with glaucoma suspect between 2012 and 2017 were selected. The study included consecutive participants who met the inclusion requirements. Sixty-one eyes of 31 patients with glaucoma suspected group and 84 eyes of 42 healthy people in the control group were included in the study. In the glaucoma suspect group, one eye of a patient was excluded because of phythisis bulbi.

In the glaucoma suspect group, visual field and/or optic disc and/or RNFL normal or suspicious, with at least one suspicious. The control group consisted of people who applied to the ophthalmology clinic for routine examination and had normal eye examination and no history of systemic disease. In both groups, previous ocular surgery, spherical 
equivalent to two diopters, ocular disease (uveitis, amblyopia, strabismus, dry eye, keratoconus, corneal opacity), and patients with systemic diseases as hypertension and diabetes mellitus, were excluded from the study.

All subjects had undergone complete ophthalmic examinations including Snellen visual acuity measurement, Goldmann applanation tonometry, slit-lamp biomicroscopy, visual field analysis (Octopus Perimetry, Haag-Streit, USA), gonioscopy, dilated fundus examination of the optic disc (with tropicamide $1 \%$ drops before fundus examinations). Central corneal thicknesses were obtained using scheimplug corneal topography (Sirius; Costruzione Strumenti Oftalmici, Florence, Italy).

Participants with media opacity that could affect the OCT images were excluded from the study. Macular thickness and volume measurements and optic disc images were obtained by us using spectral-domain OCT (Spectralis OCT; Heidelberg Engineering, Heidelberg, Germany). LCD were measured from the optic nerve head images of glaucoma suspect patients and control group. OCT examination was conducted by an investigator who was blinded to the patients' clinical information. For assessment offline analysis, OCT images were digitally stored.

\section{Ganglion cell layer and lamina cribrosa depth measurements}

Ganglion cell layer (GCL) thicknesses of the groups were measured by a retinal map analysis system. Volumetric retinal scans and layer division were completed automatically using the Spectralis OCT software. GCC variables from the GCC map were GCC average (average GCC thickness for the whole area), GCC superior (average GCC thickness for the superior half of the area), GCC inferior (average GCC thickness for the inferior half of the area), and GCC minimum (minimum GCC thickness for the whole area). In this study, we included GCC average (average GCC thickness for the whole area) for each eye of all participants.

The lamina cribrosa was evaluated by the enhanced depth imaging tecnique of OCT (EDI-OCT) (Spectralis OCT; Heidelberg Engineering,
Heidelberg, Germany). LCD was defined as the vertical distance between the reference plane in the optic nerve head, connecting the end of Bruch's membrane and anterior lamina cribrosa surface. The measurement point was determined as the center of the reference line and was obtained along a perpendicular line with a manual caliper by one observer (S.B.K)

\section{Statistical analysis}

The sample size was determined with reference to an existing study ${ }^{21}$.Using a 2 -sided type I error of 0.05 and $90 \%$ power, we needed a sample of 28 participants per group to compare the protocols.

IBM SPSS Statics for Windows v.25.0 (IBM Corp., Armank, NY, USA) program was used for data analysis. Categorical measurements were summarized as numbers and percentages and measurements as mean and standard deviation (required median and minimum-maximum). Chi-Square test or Fisher test statistics were used for categorical data analysis. The normality of the distribution of data was determined using the Kolmogorov-Smirnov test and ShapiroWilk tests. In order to compare the data in the glaucoma suspect and control groups, Student's T test was used for variables with parametric distribution, and Mann-Whitney U test for variables (LC) without parametric distribution. The cut-off for statistical significance was expressed as $P<.05$.

\section{RESULTS}

This study involved a total of 73 participants; 31 glaucoma suspect patients and 42 healthy subjects. In the glaucoma suspect group, one eye of a patient was phythisis bulbi. Finally, 61 eyes of 31 glaucoma suspect patients and 84 eyes of 42 healthy subjects were included. Table 1 summarizes the clinical demographics of all participants. There were no significant differences in age and gender between the groups. In the glaucoma suspect group mean intraocular pressure and mean Cup to Disc ratio $(C / D)$ significantly higher than the control group $(P=$ .000). Table 2 shows GCL thicknesses and LCD measurements in each group, between groups and their $P$ values. 
Table 1. Clinical and demographic characteristics of participants

\begin{tabular}{|l|c|c|c|}
\hline & Glaucoma suspect $\mathbf{( n = 3 1 )}$ & Control $\mathbf{( n = 4 2 )}$ & P \\
\hline Age & $47.7 \pm 18.9$ & $41.2 \pm 15.8$ & .11 \\
\hline Gender $(\mathrm{n}(\%))$ & & & \multirow{2}{*}{.09} \\
\hline Male & $17(54.8)$ & $15(35.7)$ & .000 \\
\hline Female & $14(45.2)$ & $27(64.3)$ & .000 \\
\hline Intraocular pressure & $14.3 \pm 1.8$ & $12.2 \pm 1.4$ & .000 \\
\hline Right intraocular pressure & $14.3 \pm 1.8$ & $12.1 \pm 1.3$ & .59 \\
\hline Left intraocular pressure & $14.5 \pm 2.1$ & $12.2 \pm 1.2$ & .73 \\
\hline Central corneal thickness & $539.8 \pm 31.1$ & $541.9 \pm 16.6$ & .6 \\
\hline Right central corneal thickness & $539.8 \pm 28.7$ & $541.8 \pm 20.8$ & .000 \\
\hline Left central corneal thickness & $539.8 \pm 33.8$ & $542.0 \pm 11.1$ & .000 \\
\hline Cup to Disc ratio & $0.5(0.0-0.9)$ & $0.0(0.0-0.5)$ & .000 \\
\hline Right Cup To Disc Ratio & $0.5(0.0-0.8)$ & $0.0(0.0-0.5)$ & \\
\hline Left Cup To Disc ratio & $0.5(0.0-0.9)$ & $0.0(0.0-0.5)$ & \\
\hline
\end{tabular}

For all ganglion cell layer thicknesses, although there were no significant differences between the groups, GCL thickness measurements were lower in the glaucoma suspect group than the control group ( $P>$ $.05)$. In the glaucoma suspect group, LCD measurements significantly higher than the control group $(P=.000)$. $\mathrm{C} / \mathrm{D}$ was significantly higher in the glaucoma suspect group than the control $\operatorname{group}(P=.000)$. In both groups, GCL thickness and
LCD parameters were measured for the right and left eye, separately (Figure 1 and 2). For GCL thickness, differences were found statistically insignificant in the right and the left eye, between two groups $(P>0,05)$. The LCD measurements were statistically higher in glaucoma suspected groups than the controls in the right and the left eye. $(P=.000)$. There was no statistically significant difference between the right and left eyes of the glaucoma suspect group.

Table 2. Ganglion cell layer and lamina cribrosa depth measurements in groups

\begin{tabular}{|l|c|c|c|}
\hline & Glaucoma suspect $(\mathbf{n}=\mathbf{3 1})$ & Control $(\mathbf{n}=\mathbf{4 2})$ & $\boldsymbol{P}$ \\
\hline Ganglion cell layer & $11.7 \pm 3.1$ & $12.2 \pm 3.2$ & .39 \\
\hline Right ganglion cell layer & $11.6 \pm 3.8$ & $12.2 \pm 3.3$ & .46 \\
\hline Left ganglion cell layer & $11.8 \pm 2.3$ & $12.1 \pm 3.2$ & .64 \\
\hline Lamina cribrosa Depth & $550(391-819)$ & $391(186-760)$ & .000 \\
\hline Right Lamina cribrosa Depth & $545(400-816)$ & $384(203-679)$ & .000 \\
\hline Left Lamina cribrosa Depth & $558(391-819)$ & $403(186-760)$ & .000 \\
\hline
\end{tabular}

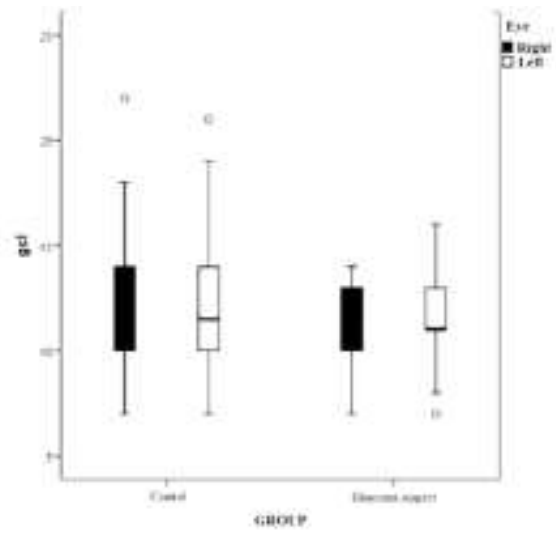

Figure 1. Ganglion cell layer thicknesses were measured for the right and left eye in both groups

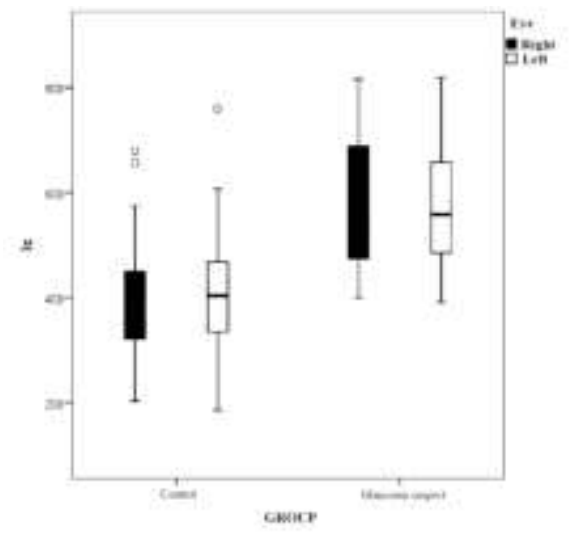

Figure 2. Lamina cribrosa depths were measured for the right and left eye in both groups 


\section{DISCUSSION}

In this study, we investigated the diagnostic power of LCD and GCC thickness in glaucoma suspect patients. In recent years, optic disc and RNFL examinations have gained more importance in the diagnosis and follow-up of glaucoma. LCD can be used as an indicator for lamina cribrosa morphology and structure. LCD is correlated with the lamina cribrosa deformation. Studies have shown that rapid glaucoma progression is related to a larger $\mathrm{LCD}^{22,23}$.

Macular region examination is important for eyes with glaucoma. GCL meausement by using OCT is a way of assesing the macular region. Various studies have shown the sensitivity and specificity of OCT to distinguish normal and glaucomatous eyes ${ }^{24}$. The initial parameter is the RNFL thickness and for the additional data, the GCL with the inner plexiform layer and the GCC $($ GCC $=$ GCL with IPL + RNFL $)$ can be used ${ }^{24,25}$.

In recent years, studies have been directed to investigate the loss in ganglion cell complex. Approximately $30-35 \%$ of the macular thickness belongs to the ganglion and nerve fiber layer. In the macula, the retinal ganglion cells diameter is $10-20$ times wider than their axons. Ganglion cells, which show a single-fold distribution in the periphery of the retina, increase in the macula and intensify. Therefore, loss of glaucoma-related ganglion cells may affect macular thickness values determined by OCT. Many parameters of the macula were used in glaucoma diagnosis and progress. These include; macular asymmetry between the two eyes, macular volume, the ratio of GCC to all macular thickness, and segmental macular GCC thickness ${ }^{26}$.

First, Zeimer et al. suggested that glaucomatous damage can be determined by decrease of macular ganglion cells. Because the macular area includes a significant portion of retinal ganglion cells ${ }^{27}$.

Lederer et al. found that in glaucoma patients macular volume decreased ${ }^{28}$, Greenfield et al. showed that macular thickness was thinner in eyes with glaucoma, similar to this study ${ }^{29}$. Another study investigated the role of the GCC in the early diagnosis of glaucoma and measured the GCC and RNFL thicknesses with OCT in 32 patients with primary open-angle glaucoma (22 early, 10 in the mild and advanced stages), 26 patients with ocular hypertension and 23 healthy cases. In patients with primary open-angle glaucoma, both values were significantly lower than those with ocular hypertension and healthy subjects ${ }^{30}$.

Lamina cribrosa depth measurement has been also used in many studies. Park et al. measured LCD in different stages of glaucoma and normal eyes. They included 86 normal eyes, 47 preperimetric glaucoma eyes, 55 intermediate glaucoma eyes and 60 advanced glaucoma eyes. They used EDI-OCT for assessing LCD. LCD was found to be increased in preperimetric glaucoma patients compared to normal eyes $^{22}$. Kim et al. also used EDI-OCT in 87 glaucoma suspect patients and in the study, they noted changes in the structure of lamina cribrosa. They reported that lamina cribrosa records could help to find out glaucoma progression. The study found out a rapid retinal nerve layer loss in eyes with advanced age, larger vertical cup disc ratio, those with larger lamina cribrosa curve index ${ }^{31}$.

In this study we found LCD was greater in the glaucoma suspect group with a greater $\mathrm{C} / \mathrm{D}$ ratio. Jung et al. found similar results. They studied with glaucoma suspect patients and showed greater lamina cribrosa depth in eyes with larger cup to disc ratio ${ }^{32}$.

The number of the participants may be a potential limitation of this study. One of the essential characteristics of this study is evaluating of GCL and LCD together. There are few studies about of GCL and LCD together in glaucoma suspect patients. The rarity of this evaluation in glaucoma suspect patients is the strength of this study.

In this study, we evaluated the lamina cribrosa depth and ganglion cell complex measurements in glaucoma suspect and healthy participants. LCD measurements were higher, GCC measurements are lower in the glaucoma suspect group. It might be a biomarker for predicting the development of glaucoma. Advances in technology have assisted in the diagnosis and treatment of glaucoma suspect, allowing ophthalmologists to confirm the condition faster and monitor progression more precisely. Further studies of a larger number of patients with glaucoma suspect are warranted to confirm our findings.

Yazar Katkıları: Çalış̧ma konsepti/Tasarımı: ŞBK, EE; Veri toplama: ŞBK, EE, İ̈H; Veri analizi ve yorumlama: ŞBK, EE, MY, İ̈H; Yazı taslağı: ŞBK, EE; İçeriğin eleştirel incelenmesi: ŞBK, EE, MY, İंH; Son onay ve sorumluluk: ŞBK, EE, İ̈H, MY; Teknik ve malzeme desteği: ŞBK, EE, İ̈H; Süpervizyon: ŞBK, EE; Fon sağlama (mevcut ise): yok. 
Etik Onay: Bu çalısma için Cukurova Üniversitesi Tıp Fakültesi Girișimsel olmayan Klinik Arastırmalar Yerel Etik Kurulundan 03.03.2017 tarih ve 62-23 sayılı kararı ile etik onay alınmıştır. Hakem Değerlendirmesi: Dış bağımsız.

Çıkar Çatışması: Yazarlar çıkar çatışması beyan ederler.

Finansal Destek: Herhangi bir kamu ve özel mali destek bulunmamaktadir.

Yazarın Notu: XVII. Çukurova Pediatri Günleri, Çukurova Pediatri Hemşireliği ve Diyetisyenliği Günleri'nde sözel bildiri olarak sunulmuştur. 21-22.02.2019, Adana

Author Contributions: Concept/Design : SBK, EE; Data acquisition: SBK, EE, IIH; Data analysis and interpretation: ŞBK, EE, MY, IIH Drafting manuscript: ŞBK, EE; Critical revision of manuscript: ŞBK EE, MY, İH; Final approval and accountability: ŞBK, EE, İ̈H, MY Technical or material support: ŞBK, EE, IIHH; Supervision: ŞBK, EE; Securing funding (if available): $\mathrm{n} / \mathrm{a}$.

Ethical Approval: For this study, ethical approval was obtained from the Local Ethics Committee of Cukurova University Faculty of Medicine Non-Interventional Clinical Research dated 03.03.2017 and numbered $62-23$.

Peer-review: Externally peer-reviewed.

Conflict of Interest: The authors declare that there is no conflict of interest.

Financial Disclosure: There isn't any public and private financia support.

Acknowledgement: This study is presented as an oral presentation at the XVII. Cukurova Pediatrics Symposium, Cukurova Pediatrics Nursing and Dietitian Symposium. (21-22.02.2019, Adana)

\section{REFERENCES}

1. NICE. Glaucoma: Diagnosis and Management. London, National Institute for Health and Care Excellence, 2017.

2. Huang D, Swanson EA, Lin CP, Schuman JS, Stinson WG, Chang W et al. Optical coherence tomography. Science. 1991;254:1178-81.

3. Medeiros FA, Zangwill LM, Alencar LM, Bowd C, Sample PA, Susanna R et al. Detection of glaucoma progression with stratus oct retinal nerve fiber layer, optic nerve head, and macular thickness measurements. Invest Ophthalmol Vis Sci. 2009;50:5741-48.

4. Lucy KA, Wollstein G. Structural, and functional evaluations for the early detection of glaucoma. Expert Rev Ophthalmol. 2016;11:367-76.

5. Hodapp E, Parrish RK, Anderson DR. Clinical Decisions in Glaucoma. St. Louis, Mosby, 1993.

6. European Glaucoma Society Terminology and Guidelines for Glaucoma, 4th Edition. Br J Ophthalmol. 2017;101:130-95.

7. Chang RT, Singh K. Glaucoma suspect: diagnosis and management. Asia Pac J Ophthalmol (Phila). 2016;5:32-7.

8. Quigley HA, Addicks EM, Green WR, Maumenee AE. Optic nerve damage in human glaucoma. ii. the site of injury and susceptibility to damage. Arch Ophthalmol. 1981;99:635-49.

9. Bellezza AJ, Rintalan CJ, Thompson HW, Downs JC, Hart RT, Burgoyne CF. Deformation of the lamina cribrosa and anterior scleral canal wall in early experimental glaucoma. Invest Ophthalmol Vis Sci. 2003;44:623-37.
10. Yang $H$, Downs JC, Bellezza AJ, Thompson $H$, Burgoyne CF. 3-D Histomorphometry of the normal and early glaucomatous monkey optic nerve head: prelaminar neural tissues and cupping. Invest Ophthalmol Vis Sci. 2007;48:5068-84.

11. Anderson DR, Hendrickson A. Effect of intraocular pressure on rapid axoplasmic transport in monkey optic nerve. Invest Ophthalmol. 1974;13:771-83.

12. Minckler DS, Bunt AH, Johanson GW. Orthograde and retrograde axoplasmic transport during acute ocular hypertension in the monkey. Invest Ophthalmol Vis Sci. 1977;16:426-41.

13. Minckler DS, Tso Mo. Light microscopic, autoradiographic study of axoplasmic transport in the normal rhesus optic nerve head. Am J Ophthalmol. 1976;82:1-15.

14. Hernandez MR. The optic nerve head in glaucoma: role of astrocytes in tissue remodeling. Prog Retin Eye Res. 2000;19:297-321.

15. Burgoyne CF, Downs JC, Bellezza AJ, Suh JK, Hart RT. The optic nerve head as a biomechanical structure: a new paradigm for understanding the role of iop-related stress and strain in the pathophysiology of glaucomatous optic nerve head damage. Prog Retin Eye Res. 2005; 24:39-73.

16. Kita Y, Kita R, Takeyama A, Takagi S, Nishimura C, Tomita G. Ability of optical coherence tomographydetermined ganglion cell complex thickness to total retinal thickness ratio to diagnose glaucoma. J Glaucoma. 2013; 22:757-62.

17. Kita Y, Kita R, Nitta A, Nishimura C, Tomita G. Glaucomatous eye macular ganglion cell complex thickness and its relation to temporal circumpapillary retinal nerve fiber layer thickness. Jpn J Ophthalmol. 2011;55:228-34.

18. Rao Hl, Zangwill LM, Weinreb RN, Sample PA, Alencar LM, Medeiros FA. Comparison of different spectral domain optical coherence tomography scanning areas for glaucoma diagnosis. Ophthalmology. 2010;117:1692-99.

19. Huang JY, Pekmezci M, Mesiwala N, Kao A, Lin S. Diagnostic power of optic disc morphology, peripapillaly retinal nerve fiber layer thickness, and macular inner retinal layer thickness in glaucoma diagnosis with fourier-domain coherence tomography. J Glaucoma. 2011;20:87-94.

20. Garas A, Vargha P, Hollo G. Diagnostic accuracy of nevre fiber layer, macular thickness and optic disc measurements made with the rtvue-100 optical coherence tomography to detect glaucoma. Eye (Lond). 2011;25:57-65.

21. Kim NR, Hong S, Kim JH, Rho SS, Seong GJ, Kim CY. Comparison of macular ganglion cell complex thickness by fourier-domain oct in normal tension glaucoma and primary open-angle glaucoma. J Glaucoma. 2013;22:133-9. 
22. Park SC, Brumm J, Furlanetto Rl et al. Lamina cribrosa depth in different stages of glaucoma. Invest Ophthalmol Vis Sci. 2015;56:2059-64.

23. Lee EJ, Kim TW, Kim M, Kim H. Influence of Lamina cribrosa thickness and depth on the rate of progressive retinal nerve fiber layer thinning. Ophthalmology. 2015;122:721-9.

24. Bussel II, Wollstein G, Schuman JS. Oct for glaucoma diagnosis, screening, and detection of glaucoma progression. Br J Ophthalmol. 2014;98:ii9-15.

25. Grewal DS, Tanna AP. Diagnosis of glaucoma and detection of glaucoma progression using spectral domain optical coherence tomography. Curr Opin Ophthalmol. 2013;24:150-61.

26. Asrani S, Rosdahl JA, Allingham RR. Novel strategy for glaucoma diagnosis. Arch Ophthalmol. 2011;129:1205-11.

27. Zeimer R, Asrani S, Zou S, Quigley H, Jampel H. Quantitative detection of glaucomatous damage at the posterior pole by retinal thickness mapping. a pilot study. Ophthalmology. 1998;105:224-31.
28. Lederer DE, Schuman JS, Hertzmark E, Heltzer J, Velazques LJ, Fujimoto JG et al. Analysis of macular volume in normal and glaucomatous eyes using optical coherence tomography. Am. J. Ophthalmol. 2003;135:838-43.

29. Grenfield DS, Bagga H, Knighton RW. Macular thickness changes in glaucomatous optic neuropathy detected using optical coherence tomography. Arch Ophthalmol. 2003;121:41-6.

30. Vidas S, Popović-suić S, Novak Lauš K, Jandroković $\mathrm{S}$, Tomić M, Jukić T et al. Analysis of ganglion cell complex and retinal nerve fiber layer thickness in glaucoma diagnosis. Acta Clin Croat. 2017;56:382-90.

31. Kim JW, Kim TW, Weinreb RN, Girard MJA, Mari JM. Lamina cribrosa morphology predicts progressive retinal nerve fiber layer loss in eyes with suspected glaucoma. Sci Rep. 2018;15;8:738.

32. Jung KI, Jeon S, Park CK. Lamina cribrosa depth is associated with the cup-to-disc ratio in eyes with large optic disc cupping and cup-to-disc ratio asymmetry. J Glaucoma. 2016;25:E536-45. 